\title{
Komodifikasi Simbol Religi dalam Iklan Marjan Edisi Bulan Ramadhan
}

\author{
M. Alqodri Ramadhan
}

Program Studi Ilmu Komunikasi, Universitas Muhammadiyah Yogyakarta, Indonesia m.alqodri.isip19@mail.umy.ac.id

Revi Yudhistira

Program Studi Ilmu Komunikasi, Universitas Muhammadiyah Yogyakarta, Indonesia revi.y.isip19@mail.umy.ac.id

Hizwa Naufal Muhammadi

Program Studi Ilmu Komunikasi, Universitas Muhammadiyah Yogyakarta, Indonesia

hizwa.naufal.isip19@mail.umy.ac.id

Diserahkan: 29 April 2021; Direvisi: 11 Juni 2021; Diterima: 11 Juni 2021

\begin{abstract}
In the current era, religion cannot be separated from commodification. The paradigm shift from religion that regulates human life which is conveyed through preaching in mosques has now begun to shift to a capital culture of commodification through advertising on television media. By using Roland Barthes' semiotic analysis, this study seeks to reveal the meaning of denotation, connotation and myths built into the Ramadan edition of the Marjan syrup television commercial. Researchers try to explain the relationship between signifier, signified, and signs, in various texts (audio visual), which form myths, to perpetuate the practice of religious commodification. The results of the discussion of this study indicate that the interest of the advertiser is to invite the public / consumers to use Marjan syrup products. Through the use of visual religious signs, it becomes something that is essential to get the empathy and sympathy of the audience to buy and use Marjan syrup products. The researcher realizes that the semiotic concept that works on the process of signifier, signified and signs, finds myths to perpetuate the consumptive ideological system and capitalism, wrapped in sacred values of religious teachings.

Keywords: Islam, Marjan Ads, Religious Commodification, Semiotics, Television Advertisement.
\end{abstract}

\begin{abstract}
Abstrak
Pada era sekarang, agama tidak terlepas dari komodifikasi. Perubahan paradigma dari agama yang mengatur kehidupan manusia yang disampaikan melalui dakwah di dalam masjid kini mulai berpindah pada budaya kapital komodifikasi melalui iklan di media televisi. Dengan menggunakan analisis semiotika Roland Barthes, penelitian ini berusaha mengungkap makna denotasi, konotasi serta mitos yang dibangun dalam iklan komersial televisi sirup Marjan edisi ramadhan. Peneliti mencoba menjelaskan hubungan antara penanda, petanda, dan tanda dalam berbagai teks (audio visual), yang membentuk mitos, hingga melanggengkan praktik komodifikasi agama. Adapun hasil dari pembahasan penelitian ini menunjukkan bahwa kepentingan pembuat iklan adalah untuk mengajak masyarakat/konsumen agar menggunakan produk sirup Marjan. Melalui penggunaan visual tanda-tanda keagamaan, menjadi sesuatu yang mutlak untuk mendapatkan empati dan simpati khalayak untuk membeli dan menggunakan produk sirup Marjan. Peneliti menyadari bahwa konsep semiotika yang bekerja pada proses penanda, petanda, dan tanda, menemukan mitos-mitos untuk melanggengkan sistem ideologi konsumtif dan kapitalisme, berbungkus nilai-nilai sakral ajaran agama.

Kata Kunci: Komodifikasi Agama, Iklan Marjan, Iklan Televisi, Islam, Semiotika.
\end{abstract}




\section{PENDAHULUAN}

Sebagai negara dengan penduduk dengan jumlah pemeluk agama Islam terbanyak di dunia, Indonesia memiliki tradisi yang dilakukan setiap tahunnya yaitu berpuasa Ramadan bagi muslim. Hal itu tak terlepas dari iklan di televisi maupun media digital menampilkan iklan yang berisi terkait materi religi, hal itu dimanfaatkan sebagai ajang untuk mengiklankan produk sirup yang menyegarkan penonton.

Produk Marjan merupakan salah satu produk sirup yang sering mengeluarkan iklan pada saat menjelang bulan ramadhan. Iklan televisi sirup Marjan menampilkan nuansa Islami dan dalam penyampaian produk menggunakan metode iklan yang memiliki series agar konsumen penasaran untuk mengetahui kelanjutannya. Selain itu, produk Marjan juga memanfaatkan hari besar seperti bulan Ramadan untuk menentukan segmentasi produk Marjan. Produk Marjan juga memanfaatkan mayoritas pemeluk agama Indonesia sebagai dakwahtainment yang merupakan istilah untuk menjelaskan tentang agama yang dikemas sesuai dengan tuntutan pasar yang disajikan dengan konsep tuntutan dan tontonan.

Berangkat dari fenomena tersebut, penelitian ini dimaksudkan untuk mengetahui bagaimana representasi komodifikasi simbol religi pada produk Marjan. Dari berbagai iklan produk sirup yang berasal dari Indonesia, Marjan merupakan produk sirup yang sangat konsisten mengeluarkan iklan pada saat bulan Ramadan serta menunjukkan identitas Islam. Marjan sendiri ingin memberi kesadaran kepada konsumen di Indonesia agar dapat membeli dan mengkonsumsi sirup Marjan pada saat puasa. Hal tersebut dibuktikan dengan iklan Marjan yang sering dikeluarkan pada saat bulan Ramadhan dan biasanya memiliki series.

Penelitian terdahulu tentang komodifikasi simbol religi dalam iklan telah dipublikasikan. Pertama, penelitian oleh Agustian Bhaskoro tentang komodifikasi simbol agama dalam iklan berlabel halal. Penelitian tersebut menemukan bahwa komodifikasi simbol agama dalam iklan televisi berlabel halal ini bisa disimpulkan sebagai sebuah transformasi nilai-nilai dari suatu agama dari yang bersifat normatif dengan landasan kepercayaan terhadap Tuhan menjadi nilai tukar yang disamakan dengan kebutuhan setiap individu berupa tayangan iklan di televisi. Terdapat unsur kesengajaan di dalamnya dengan harapan agar konsumen tertarik. Komodifikasi iklan melalui televisi ini tidak selalu bernilai negatif, namun dapat diambil nilai-nilai positif dari apa yang ditampilkan dalam iklan tersebut karena mengandung nilai-nilai Islam di dalamnya. Namun hal mendasar yang dapat diperoleh dari analisis di atas adalah kepentingan sebenarnya dari suatu produsen/ pengiklan produk adalah keuntungan ekonomi (Agustian Bhaskoro Abimana Aryasatya, 2016).

Sama halnya dengan penelitian yang dilakukan oleh Gusti Vita Riana tentang komodifikasi nilai agama dalam iklan televisi (studi analisis semiotik komodifikasi nilai agama terhadap iklan larutan Cap Kaki Tiga) menemukan terdapat tanda-tanda dan makna yang mengidentifikasikan terjadinya praktik komodifikasi nilai agama dalam iklan yaitu agama sebagai keyakinan dan kepercayaan tentang ketuhanan yang bersifat sakral dan privasi terjadi transformasi nilai menjadi nilai tukar yang bersifat komersial (Riana, 2014).

Kemudian penelitian yang dilakukan oleh Aulia Kholqiana dkk tentang representasi komodifikasi simbol religi dalam iklan Wardah. Penelitian tersebut menemukan iklan Wardah menunjukkan adanya tiga bentuk komodifikasi agama dalam iklan berlabel halal, di antaranya adalah pertama pemanfaatan ikonografi (penggambaran identitas) Islami yang digunakan untuk memasarkan produkproduk tertentu kepada konsumen. Kedua, adalah penggunaan tokoh yang berpengaruh yaitu ustadz/ustadzah ataupun bintang iklan yang Islami. Ketiga penggunaan teks-teks ataupun isi dari iklan dengan pesan Islami yang jauh dari penggunaannya (Kholqiana et al., 2020).

Terakhir adalah penelitian yang dikerjakan oleh Hidayat Surya Abadi tentang komodifikasi agama dalam iklan televisi Ramadan, yang melakukan analisis semiotika terhadap iklan televisi Ramayana edisi Ramadhan 2017. Penelitian tersebut mengemukakan bahwa komodifikasi agama, merupakan salah satu bentuk dari model masyarakat konsumsi. Pertukaran nilai sakral menjadi profan, menjadi 
sebuah keniscayaan. Di satu sisi, iklan yang diteliti memberi banyak pelajaran positif akan aplikasi salah satu ajaran agama yang utama, yakni menghormati dan membahagiakan orang tua. konsep itu diterjemahkan dengan pola kesederhanaan hidup dan keikhlasan merawat orang tua yang "sakit" akibat kehilangan memori. Namun disisi lain, pemirsa sebenarnya digiring untuk "mengiyakan" konsep konsumerisme, hedonisme, dan kapitalisme, sebagai pesan implisit dalam iklan tersebut (Abadi, 2019)

Berbeda dengan keempat penelitian di atas yang meneliti iklan berlabel halal, iklan larutan Cap Kaki Tiga, iklan Wardah, dan iklan Ramayana, penelitian ini berfokus pada iklan Marjan edisi bulan Ramadhan yang memiliki perbedaan unsur yang dimuat dalam tayangan iklan yang dipadukan antara budaya dan religi yang melekat sangat kuat. Penelitian ini perlu dilakukan karena adanya kegiatan komodifikasi di dalam iklan Marjan edisi bulan ramadhan 1432 Hijriyah. Sehingga berdasarkan permasalahan diatas peneliti tertarik untuk mengkaji tentang "Komodifikasi Simbol Religi dalam Iklan Marjan edisi Bulan Ramadhan 1432 Hijriyah”.

\section{KAJIAN PUSTAKA}

\section{KOMODIFIKASI}

Sebagai negara dengan penduduk dengan jumlah pemeluk agama Islam terbanyak di dunia, Indonesia memiliki tradisi yang dilakukan setiap tahunnya yaitu berpuasa Ramadan bagi muslim. Hal itu tak terlepas dari iklan di televisi maupun media digital menampilkan iklan yang berisi terkait materi religi, hal itu dimanfaatkan sebagai ajang untuk mengiklankan produk sirup yang menyegarkan penonton.

Produk Marjan merupakan salah satu produk sirup yang sering mengeluarkan iklan pada saat menjelang bulan ramadhan. Iklan televisi sirup Marjan menampilkan nuansa Islami dan dalam penyampaian produk menggunakan metode iklan yang memiliki series agar konsumen penasaran untuk mengetahui kelanjutannya. Selain itu, produk Marjan juga memanfaatkan hari besar seperti bulan Ramadan untuk menentukan segmentasi produk Marjan. Produk Marjan juga memanfaatkan mayoritas pemeluk agama Indonesia sebagai dakwahtainment yang merupakan istilah untuk menjelaskan tentang agama yang dikemas sesuai dengan tuntutan pasar yang disajikan dengan konsep tuntutan dan tontonan.

Berangkat dari fenomena tersebut, penelitian ini dimaksudkan untuk mengetahui bagaimana representasi komodifikasi simbol religi pada produk Marjan. Dari berbagai iklan produk sirup yang berasal dari Indonesia, Marjan merupakan produk sirup yang sangat konsisten mengeluarkan iklan pada saat bulan Ramadan serta menunjukkan identitas Islam. Marjan sendiri ingin memberi kesadaran kepada konsumen di Indonesia agar dapat membeli dan mengkonsumsi sirup Marjan pada saat puasa. Hal tersebut dibuktikan dengan iklan Marjan yang sering dikeluarkan pada saat bulan Ramadhan dan biasanya memiliki series.

Penelitian terdahulu tentang komodifikasi simbol religi dalam iklan telah dipublikasikan. Pertama, penelitian oleh Agustian Bhaskoro tentang komodifikasi simbol agama dalam iklan berlabel halal. Penelitian tersebut menemukan bahwa komodifikasi simbol agama dalam iklan televisi berlabel halal ini bisa disimpulkan sebagai sebuah transformasi nilai-nilai dari suatu agama dari yang bersifat normatif dengan landasan kepercayaan terhadap Tuhan menjadi nilai tukar yang disamakan dengan kebutuhan setiap individu berupa tayangan iklan di televisi. Terdapat unsur kesengajaan di dalamnya dengan harapan agar konsumen tertarik. Komodifikasi iklan melalui televisi ini tidak selalu bernilai negatif, namun dapat diambil nilai-nilai positif dari apa yang ditampilkan dalam iklan tersebut karena mengandung nilai-nilai Islam di dalamnya. Namun hal mendasar yang dapat diperoleh dari analisis di atas adalah kepentingan sebenarnya dari suatu produsen/pengiklan produk adalah keuntungan ekonomi (Aryasatya, 2016).

Sama halnya dengan penelitian yang dilakukan oleh Gusti Vita Riana tentang komodifikasi nilai agama dalam iklan televisi (studi analisis semiotik komodifikasi nilai agama terhadap iklan larutan 
Cap Kaki Tiga) menemukan terdapat tanda-tanda dan makna yang mengidentifikasikan terjadinya praktik komodifikasi nilai agama dalam iklan yaitu agama sebagai keyakinan dan kepercayaan tentang ketuhanan yang bersifat sakral dan privasi terjadi transformasi nilai menjadi nilai tukar yang bersifat komersial (Riana, 2014).

Kemudian penelitian yang dilakukan oleh Aulia Kholqiana dkk tentang representasi komodifikasi simbol religi dalam iklan Wardah. Penelitian tersebut menemukan iklan Wardah menunjukkan adanya tiga bentuk komodifikasi agama dalam iklan berlabel halal, di antaranya adalah pertama pemanfaatan ikonografi (penggambaran identitas) Islami yang digunakan untuk memasarkan produkproduk tertentu kepada konsumen. Kedua, adalah penggunaan tokoh yang berpengaruh yaitu ustadz/ustadzah ataupun bintang iklan yang Islami. Ketiga penggunaan teks-teks ataupun isi dari iklan dengan pesan Islami yang jauh dari penggunaannya (Kholqiana et al., 2020).

Terakhir adalah penelitian yang dikerjakan oleh Hidayat Surya Abadi tentang komodifikasi agama dalam iklan televisi Ramadan, yang melakukan analisis semiotika terhadap iklan televisi Ramayana edisi Ramadhan 2017. Penelitian tersebut mengemukakan bahwa komodifikasi agama, merupakan salah satu bentuk dari model masyarakat konsumsi. Pertukaran nilai sakral menjadi profan, menjadi sebuah keniscayaan. Di satu sisi, iklan yang diteliti memberi banyak pelajaran positif akan aplikasi salah satu ajaran agama yang utama, yakni menghormati dan membahagiakan orang tua. konsep itu diterjemahkan dengan pola kesederhanaan hidup dan keikhlasan merawat orang tua yang "sakit" akibat kehilangan memori. Namun disisi lain, pemirsa sebenarnya digiring untuk "mengiyakan" konsep konsumerisme, hedonisme, dan kapitalisme, sebagai pesan implisit dalam iklan tersebut (Abadi, 2019)

Berbeda dengan keempat penelitian di atas yang meneliti iklan berlabel halal, iklan larutan Cap Kaki Tiga, iklan Wardah, dan iklan Ramayana, penelitian ini berfokus pada iklan Marjan edisi bulan Ramadhan yang memiliki perbedaan unsur yang dimuat dalam tayangan iklan yang dipadukan antara budaya dan religi yang melekat sangat kuat. Penelitian ini perlu dilakukan karena adanya kegiatan komodifikasi di dalam iklan Marjan edisi bulan ramadhan 1432 Hijriyah. Sehingga berdasarkan permasalahan diatas peneliti tertarik untuk mengkaji tentang "Komodifikasi Simbol Religi dalam Iklan Marjan edisi Bulan Ramadhan 1432 Hijriyah”.

\section{REPRESENTASI}

Representasi adalah proses bagaimana kita memberi makna pada sesuatu melalui bahasa. Untuk mempresentasikan juga berarti menyimbolkan, untuk mewakili, menjadi contoh, atau menjadi pengganti dari sesuatu (Hall, 1997). Komodifikasi agama berarti mengubah agama menjadi sesuatu yang dapat dijual, serta membawanya pada berbagai skala serta cara transaksi pasar, sehingga agama menjadi komoditas untuk diperjual belikan. Hal ini dapat dipengaruhi adanya perubahan teknologi ataupun kondisi sosial ekonomi yang mendorong untuk pencarian moral, kekayaan spiritual dan kesalehan identitas.

Komodifikasi agama merupakan konstruksi sejarah dan budaya yang kompleks, terlepas dari ciriciri komersialnya yang jelas. Mereka diproduksi dalam konteks budaya tertentu, dan dengan demikian, membutuhkan pemahaman tentang kerangka budaya untuk membuka signifikansi simbolis dan sosioekonomi mereka. Proses pembuatan komoditas sangat inventif dan secara khusus tertanam dalam lintasan ekonomi pasar lokal-global dan ledakan religius postmodern. Komodifikasi agama tidak serta merta mengarah pada agama atau menghasilkan bentuk dan gerakan keagamaan baru yang menentang keyakinan dan praktik organisasi keagamaan yang dilembagakan. (Pattana Kitiarsa, 2007)

Sebenarnya bukan hanya agama. Komodifikasi bisa terjadi pada aspek apa saja, dengan indikasi seperti menukar "kesakralan" nilai atau norma, menjadi lebih profan, atau bersifat materi. Komodifikasi agama berarti mengubah agama menjadi sesuatu yang dapat dijual, serta membawanya pada berbagai skala serta cara transaksi pasar, sehingga agama menjadi komoditas untuk diperjual 
belikan. Hal ini dapat dipengaruhi adanya perubahan teknologi ataupun kondisi sosial ekonomi yang mendorong untuk pencarian moral, kekayaan spiritual dan kesalehan identitas.

Sedangkan maksud dari komodifikasi Islam sendiri mengacu pada pengertian Greg Fealy yang mana berasal dari kamus bahasa Inggris Oxford tentang pengertian commodity (barang jualan) adalah sesuatu yang (1) memiliki kualitas yang diinginkan atau berguna; dan (2) benda jualan atau 'objek perdagangan'. Jadi komodifikasi Islam dapat dimaknai sebagai komersialisasi (memperdagangkan) Islam atau berbaliknya keimanan dan simbol-simbolnya menjadi sesuatu yang bisa diperjual belikan untuk mendapatkan untung (Fealy, 2008). Meskipun Greg Fealy menyadari hal ini rawan mengundang perdebatan karena seolah motivasi ekonomi lebih menjadi ikatan dibandingkan dengan adanya motivasi keagamaan. Ia tidak menafikan pula adanya motivasi "murni" dalam motivasi keagamaan.

\section{METODE PENELITIAN}

Riset ini berupaya menjawab permasalahan mengenai komodifikasi unsur religi dalam iklan Marjan. Untuk mendapatkan jawaban bersumber pada permasalahan di dalam riset ini memakai metode semiotika. Semiotika adalah teori bahasa yang merupakan hasil pemikiran dari Ferdinand de Saussure dalam buku yang berjudul Linguistics Course in General (pertama kali diterbitkan pada tahun 1916). Metode semiotik mempelajari sistem dan aturan yang memungkinan tanda mempunyai makna, selain itu juga Semiotik membagi isi makna teks menjadi beberapa bagian, dan menjangkau dengan wacana yang lebih luas. Saussure menolak asumsi bahwa bahasa hanya mencerminkan kenyataan dan menyarankan bahwa bahasa beroperasi dalam sistemnya sendiri. Sistem ini membangun arti dalam bahasa - makna tidak tumbuh secara alami atau unik. Ia menyebut pendekatan ini semiologi, yang berarti riset tentang tanda, namun kita akan menggunakan istilah yang generik untuk pendekatan ini, yaitu semiotika. Tanda (kata) seperti 'tikus', misalnya, memiliki dua sifat: bunyi dan ide gagasan. Namun tidak terdapat ikatan antara suara serta ide: opsi suara tertentu buat menamai ide yang diberikan betul- betul sewenang- wenang. Saussure mengatakan kalau tanda bekerja selaku sesuatu sistem, tanda- tanda (yaitu kata- kata) yang membentuk sesuatu bahasa sanggup menunjukkan ide- ide secara pas sebab berbeda dari isyarat lain: Bahasa merupakan sistem sebutan yang silih tergantung di mana nilai tiap sebutan dihasilkan sekedar dari kehadiran simultan dari orang lain. Jadi bahasa terstruktur lewat perbandingan, serta ide yang berbeda tergantung pada suara yang berbeda, ataupun perbandingan fonetik yang membolehkan untuk membedakan kata ini dari yang lain, sebab perbandingan membawa arti (Laughey, 2007).

Dengan demikian, semiotika berkisar tentang riset tentang tanda dalam teks. Tanda (sign) meliputi 2 aspek, ialah indikator (signifiant), serta petanda (signified). Penanda bisa dipahami selaku wujud/ bentuk raga. Indikator dapat berbentuk bunyi, foto, huruf, visual serta sejenisnya. Sebaliknya petanda merupakan konsep ataupun makna dari apa yang diisyarati. Relasinya antara keduanya bersifat "diadaadakan" (arbitrary), yang berarti tidak terdapat hubungan yang sifatnya alamiah antara penanda serta petanda. Semiotika dengan demikian ialah kedekatan tripartit ialah tanda (sign) yang merupakan gabungan dari penanda (signifier) serta petanda (signified) (Hartley, 2003).

Berikutnya, Saussure mengintroduksi mengenai langue serta parole. Langue adalah inti serta penyebutan arti bahasa dalam taraf sosial budaya, sedangkan parole ialah aktualisasi bahasa pada tahapan seseorang. Gampangnya, langue dapat disebut sebagai sistem bahasa yang berlaku, sebaliknya parole ialah bagaimana seseorang berbahasa pada sistem tersebut. Dengan demikian, maka parole terikat memakai langue.

Pemikiran Saussure kemudian diteruskan oleh Roland Barthes. Barthes memberikan kontribusi yang krusial untuk memahami kiprah media dalam reproduksi ideologi. Barthes mengacu pada karya Saussure dan teorinya mengenai semiotika, yang sudah memasuki dunia media dan penelitian sosial pada 1960-an. Ia berpendapat mengenai pentingnya media di dalam hal penyebaran ideologi atau pandangan dunia didasarkan pada kemampuan mereka untuk membangun tanda dan citra dengan 
tahap tertentu. Dia meneliti cara di mana tanda-tanda (yaitu, gambar, kata-kata, musik, dan objek) menafsirkan makna yang lebih dalam di dalam masyarakat dan budaya daripada yang tampak sangat melekat di dalamnya. Secara spesifik ia melihat media, melalui proses pemaknaan, membuat arti dan perspektif tertentu dalam masyarakat tampak nyata dan masuk akal (Williams, 2003).

Pemikiran Barthes yang berjasa besar dalam memaknai tanda mengenai mitos. Gagasan pemikiran yang sebenarnya masih meneruskan anggapan Saussure mengenai relasi bahasa dan makna atau antara penanda dan petanda. Semiotika yang dibangun Saussure condong menyampaikan makna sebagai apa yang diartikan oleh tanda. Dengan demikian, tradisi semiotika pada awal kemunculannya cenderung berhenti sebatas pada makna-makna secara generik alias semiotika denotasi.

Oleh Barthes, gagasan pemaknaan secara umum atau pemaknaan pada taraf primer (primary signification) dikaji lebih lanjut. Barthes menjelaskan bahwa terdapat arti lain yang benar-benar bermain dalam level yang lebih mendalam, yakni dalam taraf konotasi atau pemaknaan sekunder (secondary signification) pada iklan Marjan.

Dengan demikian, pemikiran Saussure dikembangkan oleh Barthes dengan membongkar praktik pertandaan pada taraf pemaknaan tanda. Konotasi bagi Barthes justru mengubah arti umum sesuatu hal yang ia nyatakan sebagai mitos, dan mitos ini mempunyai konotasi terhadap ideologi khusus. Skema pemaknaan mitos itu oleh Barthes digambarkan sebagai berikut:

\begin{tabular}{|l|l|l|}
\hline 1. Penanda & 2. Petanda & \\
\hline $\begin{array}{c}\text { 3. Tanda } \\
\text { I. PENANDA }\end{array}$ & II. PETANDA \\
\hline III. TANDA & \\
\hline
\end{tabular}

Gambar 1. Semiotika Model Roland Barthes

Sumber: Roland Barthes (dalam Storey, 1994)

Secara operasional dalam penelitian ini semiotika diterapkan dengan melakukan kajian terhadap tanda-tanda yang terdapat dalam iklan sirup Marjan "Marjan versi beladiri”. Iklan Marjan yang diriset ditempatkan sebagai teks yang merupakan rajutan dari berbagai tanda. Tanda-tanda yang ada baik dalam bentuk gambar, tulisan maupun suara diambil dari shot dan scene yang ada dalam iklan Marjan tersebut. Pada tahap hasil penelitian, peneliti akan menyajikan pemaknaan secara denotatif dan konotatif, yang kemudian dilanjutkan dengan pembahasan yang menganalisis temuan penelitian dengan intertekstualitas dengan berbagai teori yang relevan. 


\section{HASIL DAN PEMBAHASAN}

HASIL

Pada bagian ini, peneliti memaparkan hasil dan pembahasan dengan menggunakan iklan yang dikeluarkan oleh Marjan pada tahun 2011. Peneliti membagi ke dalam empat unit analisis. Berikut merupakan hasil analisis melalui tiga tahapan semiotika Roland Barthes, yaitu denotasi, konotasi dan mitos.

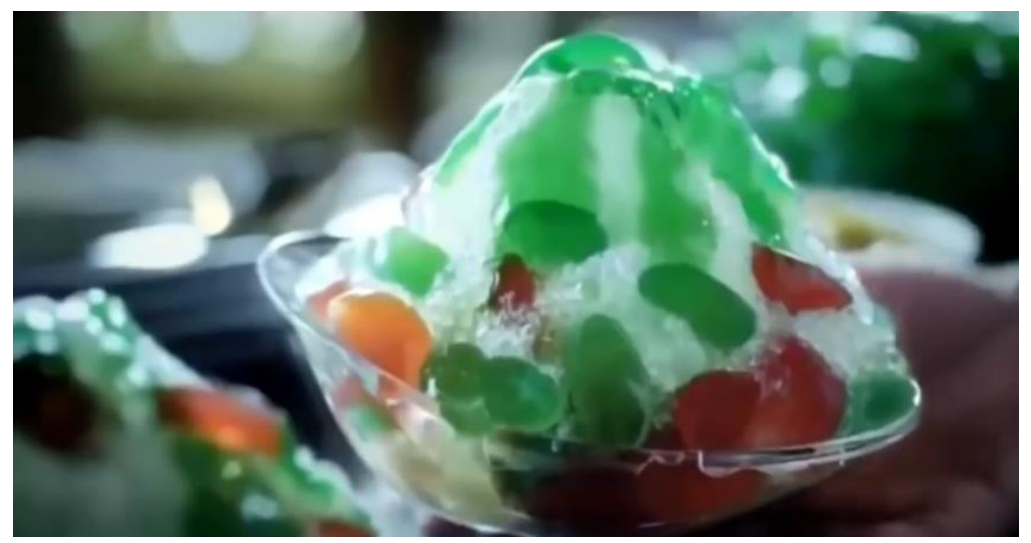

Gambar 2. Iklan Marjan tahun 2011

Makna denotasi: Dapat diuraikan, penanda dalam potongan iklan di atas adalah campuran buah pepaya dan kolang-kaling yang diberi es yang di atasnya diberi sirup warna hijau. Aspek petanda dari penanda ini adalah es serut. Petanda yang berada dalam potongan gambar 1 dari iklan di atas menunjukan saat berbuka puasa dengan yang manis. Digambarkan dengan es serut yang diberi sirup Marjan di atas serutan es. Ditambah juga dengan buah pepaya dan kolang-kaling yang rasanya manis.

\section{Makna konotasi: Ketika berbuka harus berbuka dengan yang manis.}

Gambar di atas menunjukkan pesan bahwa ketika berbuka, berbukalah dengan yang manis. Hal ini juga merupakan salah satu anjuran para ulama. Menurut para ulama berbuka dengan yang manis dapat memulihkan penglihatan yang menurun akibat puasa. Dengan begini posisi makanan atau minuman yang manis akan menjadi sebuah takjil wajib bagi semua orang muslim sebelum makan dengan menu yang berat. Seperti yang dapat dilihat pada kehidupan sehari-hari, banyak orang yang menjual takjil dengan rasa dasar yang manis seperti es campur, es buah, es kelapa muda dengan tambahan gula jawa atau sirup, jajanan tradisional, dan lain-lain.

\section{Mitos: Ketika berbuka harus berbuka dengan yang manis.}

"Berbukalah dengan yang manis". Ungkapan itu sering kita dengar di iklan-iklan televisi pada bulan Ramadhan. Istilah Takjil pun biasa digunakan untuk makanan ringan atau minuman yang disajikan untuk membatalkan puasa, seperti kolak, aneka es, dan hidangan sejenis yang sarat akan gula (Muaris, 2009). Dalam iklan tersebut bersifat menggiring opini. Pemirsa digiring agar lebih baik menggunakan sirup Marjan saat berbuka. Sebab selain manis, produk ini diklaim menyehatkan. Maka seolah-olah, berbuka menggunakan produk yang manis dan sehat itu, sudah termasuk memenuhi anjuran Nabi Muhammad SAW, untuk berbuka dengan sesuatu manis. Mitos ini menempatkan sirup Marjan memiliki pembenaran secara religi sebagai sirup yang layak dan seharusnya diminum saat berbuka puasa. Sirup Marjan direpresentasikan sebagai sirup yang manis, dan karena manis maka memiliki nilai religi, yang jika diminum untuk berbuka maka para peminumnya akan mendapat pahala. 


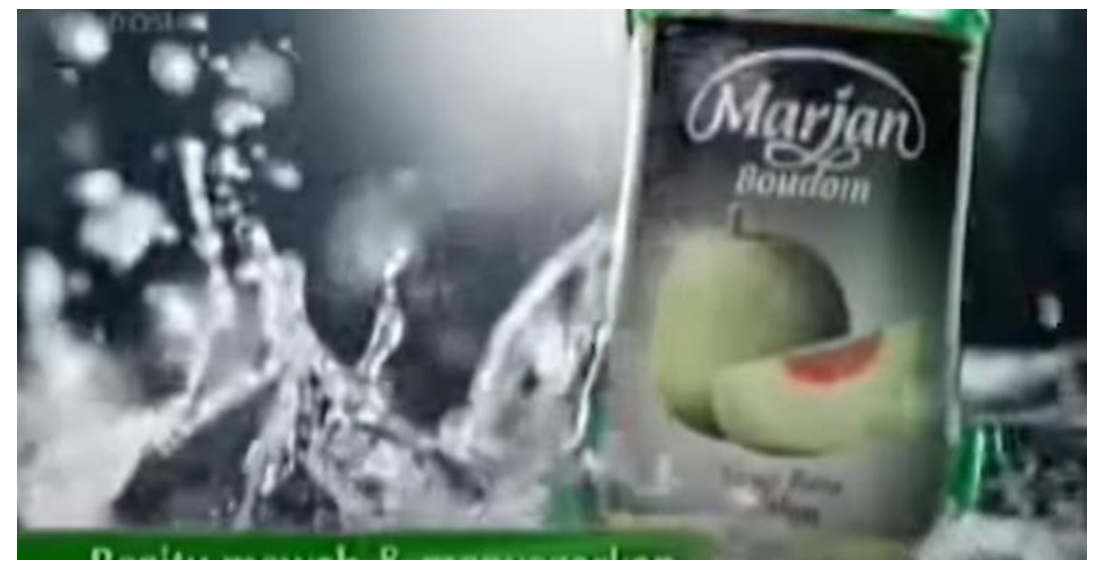

Gambar 3. Iklan Marjan tahun 2011

Makna Denotasi: Dilihat dari tangkapan layar tersebut, petanda yang berada didalam potongan iklan tersebut adalah tampilan sirup marjan yang identik dengan warna hijau. Selain itu, percikan air yang ditambahkan menambahkan kesan menyegarkan setelah minum sirup tersebut. Ditambah juga narasi audio yang menyebutkan "Segarkan Hati di Bulan Suci”, yang menambah kesan iklan Ramadhan.

\section{Makna Konotasi: Iklan Sirup diidentikan dengan visual dan narasi yang sangat mendukung guna membangun suasana momentum Ramadhan.}

Dalam memanfaatkan momentum Ramadhan dengan sebaik-baiknya, iklan yang dibuat sebaik mungkin dengan memanfaatkan visual dan audio yang mendukung. Produsen iklan juga memperhatikan dari segi visual yang dibentuk direpresentasikan dengan gambar yang mendukung. Iklan Marjan yang identik dengan warna hijau, berpadu dengan gambar air terpercik dari yang merepresentasikan "minuman yang menyegarkan". Hal itu ditambah dengan narasi audio yang berbunyi "Segarkan Hati, di Bulan Suci” sangat membangun suasana religi di dalam iklan tersebut.

\section{Mitos: Setiap iklan sirup diidentikan dengan kesegaran.}

Komodifikasi mengacu pada proses mengubah nilai guna menjadi nilai tukar, mengubah produk yang nilainya ditentukan oleh kemampuan mereka untuk memenuhi individu dan kebutuhan sosial ke dalam produk yang nilainya ditentukan oleh harga pasar mereka (Mosco, 2009). Gambaran visual yang mendukung dan juga dimanfaatkan di dalam momentum Ramadhan, iklan ini menawarkan pemaknaan "kesegaran di bulan suci" yang diwujudkan dalam visual sirup dan percikan air. Selain itu di dalam iklan diberikan narasi audio dan tampilan visual yang mendukung bahwa Sirup Marjan direpresentasikan lekat dengan simbol dan aktivitas keislaman. Internalisasi berbagai nilai baik agama, sosial, budaya, dan lain-lain akan menjadi kapital sosial yang mempengaruhi tindakan dan praktik sosialnya (Munfarida, 1970). Dalam iklan Marjan ini, budaya konsumen dikemas dengan praktek penandaan (audio-visual) yang memperlihatkan simbol religi yang sebenarnya ada kepentingan produsen (kelas kapitalis) untuk memasarkan produknya. Aktivitas yang melekat adalah silaturahmi saat lebaran. Sirup Marjan membangun praktek representasi sebagai sirup keluarga muslim yang mengartikan bahwa religi hanya dijadikan sebagai simbol dari budaya konsumen. 


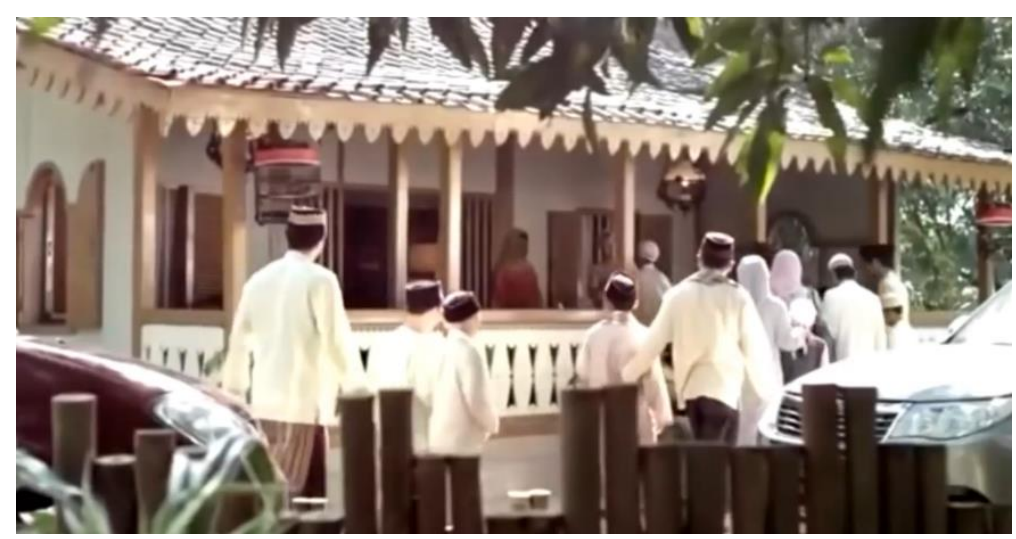

Gambar 4. Iklan Marjan tahun 2011

Makna denotasi: Dapat diuraikan, petanda yang berada dalam potongan gambar 3 dari iklan di atas adalah adanya beberapa orang baik laki-laki maupun perempuan di mana laki-laki yang ada di dalam gambar tersebut terlihat menggunakan peci, baju muslim, dan kain sarung. Sedangkan perempuan di dalam gambar terlihat menggunakan hijab dan baju gamis. Pada gambar di atas juga terlihat sebuah rumah kuno dengan lampu "jadul" yang menghiasi rumah tersebut serta terlihat pula terdapat dua buah mobil sedan yang terparkir di depan rumah. Tidak hanya itu, terdapat pula audio latar belakang takbir yang berbunyi "Allahu Akbar.. Allahu Akbar.." mengiringi suasana rumah yang didatangi oleh saudara yang menggunakan mobil.

\section{Makna konotasi: Takbir biasanya dikumandangkan ketika menjelang hari raya Idul Fitri dan berarti bahwa bulan ramadhan telah usai.}

Screenshot pada iklan ini menampilkan makna bahwa kalimat takbir biasanya dikumandangkan ketika hari raya. Berlatar belakang dengan sebuah rumah yang dikunjungi oleh kerabat dan tetangga sekitar. Hal ini juga menandakan bahwa bulan ramadhan telah usai. Momen ini memang identik dengan suasana hari raya Idul Fitri yang terjadi. Masjid-masjid pada umumnya memang menyetel audio takbir agar memeriahkan suasana hari raya. Terlihat pula orang-orang yang terdapat di dalam gambar berkunjung ke rumah kuno yang mana merupakan rumah dari kakek dan nenek keluarga tersebut. Dengan menggunakan mobil sedan dengan kapasitas dua jok yang berarti mobil tersebut merupakan mobil yang biasa digunakan untuk sebuah keluarga.

\section{Mitos: Takbir dikumandangkan ketika hari raya Idul Fitri.}

Takbir selalu menyertai orang muslim dalam banyak ibadah dan berbagai bentuk ketaatan. Seorang muslim akan bertakbir membesarkan Allah ketika ia telah berhasil menyempurnakan hitungan puasa Ramadhan dan dalam ibadah Haji, takbir sangat penting dan punya kedudukan tinggi (Maulida, 2019). Untuk membangun suasana iklan yang ditayangkan pada bulan Ramadhan dan Idul Fitri. Tentunya unsur agama yang dikaitkan di dalam iklan Marjan tidak luput darinya, hal ini untuk menegaskan bahwa suasana yang sedang ditayangkan di dalam iklan adalah suasana "kemenangan" Idul Fitri. Sirup Marjan direpresentasikan lekat dengan simbol dan aktivitas keislaman. Simbol yang berkait dengan sirup Marjan adalah peci, jilbab, dan baju muslim. Aktivitas yang melekat adalah silaturahmi saat lebaran. Sirup Marjan membangun praktik representasi sebagai sirup keluarga muslim dan bisa diminum oleh keluarga muslim, baik dari anak-anak, orang tua, bahkan sampai kakek nenek. 


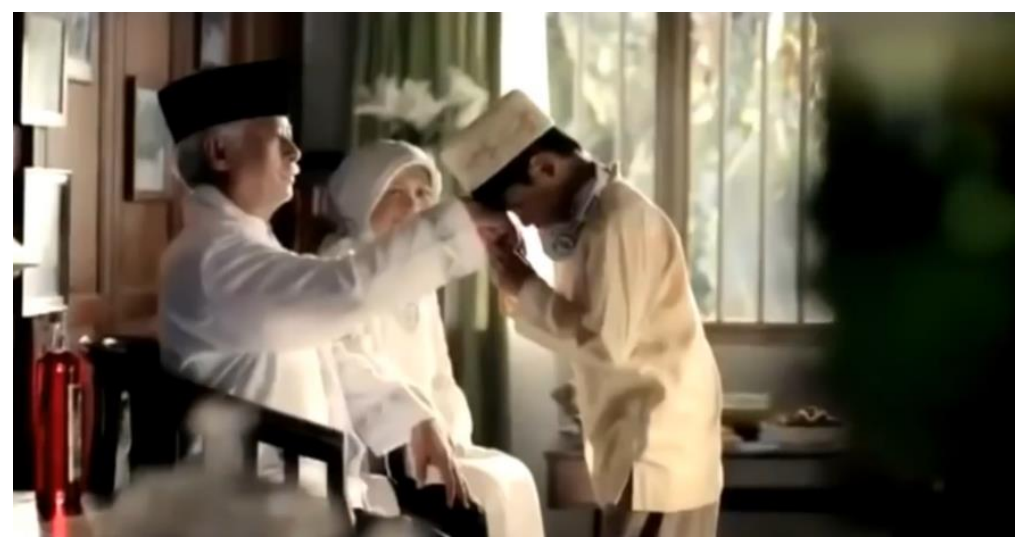

Gambar 5. Iklan Marjan tahun 2011

Makna denotasi: Dapat diuraikan, petanda yang berada dalam potongan gambar 4 dari iklan di atas adalah orang-orang yang menggunakan pakaian muslim. Laki-laki tua (kakek) di dalam gambar terlihat menggunakan peci hitam, baju muslim berwarna putih dan kain sarung dengan keadaan yang sedang duduk di kursi. Sedangkan anak kecil pada gambar terlihat juga mengenakan peci putih, baju muslim berwarna coklat dan kain sarung namun dalam keadaan berdiri. Kemudian, perempuan tua (nenek) di dalam gambar terlihat menggunakan hijab dan baju gamis berwarna putih. Berlatar belakang di dalam ruangan terlihat juga anak kecil yang meletakkan tangan kakeknya pada keningnya.

\section{Makna konotasi: Halal Bihalal merupakan tradisi saat hari raya Idul Fitri.}

Halal Bihalal merupakan momen silaturahmi dan saling memaafkan dengan keluarga dan kerabat. Momen ini merupakan momen paling spesial dalam hari raya Idul Fitri. Suasana sangat menggembirakan dan menyenangkan karena keluarga dan kerabat saling berkumpul. Dari gambar di atas, kita bisa melihat bahwa saat hari raya Idul Fitri orang-orang Islam identik dengan menggunakan pakaian muslim, mengenakan peci bagi laki-laki, dan menggunakan hijab bagi perempuan. Ditambah dengan momen saling bermaaf-maafan antara kerabat. Terutama antara yang muda meminta maaf terlebih dahulu dengan yang tua agar terkesan sopan. Terlihat juga terdapat seorang cucu yang ingin meminta maaf pada kakeknya. Namun ia seperti takut untuk meminta maaf karena raut wajah kakeknya yang terlihat tidak senang mengingat sikapnya dulu ketika tiba di rumah kakeknya yang terkesan tidak acuh.

\section{Mitos: Halal Bihalal merupakan tradisi saat hari raya Idul Fitri.}

Di dalam al-Qur'an dan hadis tidak disebutkan secara eksplisit tentang istilah halal bihalal. Hal ini bukan berarti halal bihalal termasuk ajaran Islam yang ilegal. Dalam penamaan istilah halal bihalal memang tidak ada dasar yang jelas, akan tetapi nilai-nilai ajaran dan praktik dalam halal bihalal memiliki dasar hukum yang kuat dalam al-Qur'an dan hadis (Zulfikar, 2018). Seperti dasar hukum saling memaafkan yang terdapat pada surat Asy Syura ayat 40 yang artinya "Barangsiapa yang memaafkan dan mendamaikan maka pahalanya dari Allah SWT".

Halal Bil Halal pernah menjadi perdebatan. Tradisi Halal Bihalal sendiri dikatakan tidak sesuai dengan kaidah Arab karena Halal Bihalal adalah Bahasa Arab orang-orang Indonesia.

\section{PEMBAHASAN}

Jalaludin Rahmat (dalam Saefulloh, 2009) pernah mengungkapkan bahwa masyarakat esok akan ditandai dengan dominasi teknologi komunikasi, yang sebagian besar pekerjaan akan terletak pada teknologi informasi, dan sektor informasi yang dikomputerisasi dengan hebatnya. Kini setiap gerak langkah kita seolah dikendalikan oleh kemajuan teknologi. Perkembangan teknologi informasi yang pesat saat ini memiliki imbas pada perubahan kehidupan masyarakat di segala bidang Memanfaatkan 
teknologi komunikasi dan informasi dalam kehidupan masyarakat telah menjadi tren, dan memiliki nilai (prestise) atau kelas dalam kehidupan sosial dan budaya. Akibatnya, seseorang yang tidak dapat beradaptasi dengan kecanggihan teknologi (atau gaptek: gagap teknologi) dianggap sebagai kelompok masyarakat tradisional, konservatif, dan kuno. Saat ini, pemanfaatan teknologi sudah menjadi tanda konsumerisme, yang telah menghegemoni kehidupan masyarakat sebagai sebuah keniscayaan. Terlebih dengan perkembangan industri media, terutama televisi saat ini, yang telah menjadikan perubahan mendasar dalam budaya masyarakat. Sementara itu, Pattana Kitiarsa dalam bukunya menyebutkan bahwa komodifikasi agama merupakan konstruksi sejarah dan budaya yang kompleks, terlepas dari ciri-ciri komersialnya yang jelas. Mereka diproduksi dalam konteks budaya tertentu, dan dengan demikian, membutuhkan pemahaman tentang kerangka budaya untuk membuka signifikansi simbolis dan sosio ekonomi mereka.

Dalam konteks yang lebih sempit, bisa kita lihat pada mayoritas iklan Ramadhan yang dibuat selalu menggunakan simbol Islam, sebagai daya tarik produk. Dalam memanfaatkan momentum ini, seluruh pengiklan memasukkan unsur religi yang tidak sesuai porsi. Momentum ini menjadi sangat eksklusif dikarenakan Ramadhan hanya terjadi sekali dalam setahun, maka tak ayal para pengiklan saling bahu membahu dalam membuat iklan yang memiliki unsur religi yang teramat kuat. Misalnya pada iklan Marjan edisi Ramadhan. Dalam iklan tersebut bersifat menggiring opini pemirsa digiring agar lebih baik menggunakan sirup Marjan saat berbuka. Di sinilah indikasi komodifikasi agama dalam iklan televisi, sudah digunakan dalam berbagai iklan, terutama saat Ramadhan. Alhasil, umat Islam benarbenar dianggap sebagai "pasar media” yang potensial.

Berhubungan dengan representasi, Marjan selalu mempresentasikan iklannya saat bulan ramadhan karena masyarakat berpikir bahwa minuman manis cocok disantap saat berbuka puasa. Bulan ramadhan juga bisa dijadikan kesempatan untuk meningkatkan brand awareness, mendapatkan konsumen baru, dan tentunya memperoleh keuntungan yang lebih banyak. Hal itu dipahami sangat baik oleh kalangan pebisnis atau produsen apapun, dengan melihat perubahan perilaku konsumen di bulan suci tersebut. Tak heran, jika mereka rela mengeluarkan belanja iklan besar selama bulan Ramadhan, tentu saja dengan kemasan yang bernuansa Ramadhan. Hal tersebut dilakukan pengiklan selama beberapa tahun terakhir sehingga menimbulkan rasa penasaran masyarakat dengan iklan ini. Maka, timbul stigma yang berkembang di masyarakat mengenai iklan sirup Marjan "Kalau iklan Marjan sudah tayang, berarti sudah mau dekat Bulan Ramadhan”.

Dalam perjalanannya, Iklan Marjan selalu ditayangkan dan dikemas dengan materi yang sangat baik sehingga penonton tak pernah ketinggalan dengan cerita yang berbeda-beda setiap tahunnya. Pengiklan semakin tahun semakin berbenah, pada iklan tahun 2019 dan 2020 menampilkan cerita sejarah tradisional yang dapat menarik pemirsa untuk menonton iklan tersebut. Tak berhenti di situ saja, karena kesuksesan Marjan dalam mengiklankan produknya dengan memanfaatkan momentum ini, banyak supermarket ritel di Indonesia yang menaruh produk sirup ini di rak paling depan karena sedang dicari untuk minuman berbuka puasa atau sekedar hadiah ketika 'Idul Fitri nanti.

\section{KESIMPULAN}

Dalam iklan yang diteliti, yakni iklan Marjan edisi bulan Ramadan, ditemukan tanda-tanda dan makna yang mengidentifikasikan terjadinya praktik komodifikasi nilai agama dalam iklan tersebut. Proses komodifikasi yang muncul pada Marjan edisi bulan ramadhan merupakan komodifikasi konten, tampak dari tanda-tanda serta penggambaran cerita iklan tersebut. Komodifikasi konten media terjadi melalui rekonstruksi realitas yang dalam perihal ini adalah Agama Islam. Marjan mencoba menjual pesannya pada khalayak melalui iklan-iklan yang ditayangkan pada saat bulan ramadhan serta menggunakan tema Islami. Dalam iklan ini pula, pemakaian unsur nilai-nilai keagamaan terasa sangat kokoh kala dalam iklan tersebut memperlihatkan visualisasi yang menyerupai dengan realitas kehidupan masyarakat. Iklan Marjan menunjukan adanya dua bentuk komodifikasi agama, diantaranya adalah pertama pemanfaatan ikonografi (penggambaran identitas) Islami yang digunakan 
untuk menunjukkan suasana bulan ramadhan. Kedua, adalah penggunaan audio ataupun isi dari iklan dengan pesan yang Islami.

\section{PERSANTUNAN}

Artikel ini disusun sebagai bagian dari tugas kuliah Kajian Kritis Iklan di Program Studi Ilmu

Komunikasi Universitas Muhammadiyah Yogyakarta tahun akademik 2020/2021. Tim penulis menghaturkan terima kasih kepada Dr. Fajar Junaedi, dosen pengampu mata kuliah yang telah membantu dan mendukung penulis selama proses penelitian ini berlangsung sampai dengan terbitnya publikasi atas hasil penelitian ini.

\section{REFERENSI}

Abadi, H. S. (2019). Komodifikasi Agama Dalam Iklan Televisi Ramadhan (Analisis Semiotika Terhadap Iklan TV Ramayana Edisi Ramadhan 2017).

Aryasatya, A. (2016). Komodifikasi Agama Melalui Iklan Televisi (Studi Kasus Iklan Televisi Berlabel Halal). Pustaka Ilmiah, 2(2), 190-199.

Alva Orlandini, H. (2003). Biblioteca Hombres del Perú. Vol. 1. https://books.google.com.pe/books?id=iOJyAiS2gGoC\&dq

Fealy, G. and S. W. (2008). Expressing Islam: Religious Life and Politics in Indonesia. In ISEAS Publishing. https://doi.org/10.1355/9789812308528-017

Hall, S. (1997). Representation: Cultural Representation and Signifying Practices, 1-63.

Hartley, J. (2003). A short history of cultural studies. A Short History of Cultural Studies, 1-189. https://doi.org/10.4135/9781446216934

Kholqiana, A., Fauzianin, Q., \& Azzahra, S. T. (2020). Representasi Komodifikasi Simbol Religi dalam Iklan Wardah. Jurnal Audiens, 1(2). https://doi.org/10.18196/ja.12023

Laughey, D. (2007). Key Themes in Media Theory, 1-29.

MAULIDA. (2019). Rangkaian Lafal Takbir Dua Hari Raya (Perspektif Nahdlatul Ulama dan Muhammadiyah). Rabit: Jurnal Teknologi Dan Sistem Informasi Univrab, 1(1), 2019.

Mosco, V. (2009). The Political Economy of Communication, 1-268. https://doi.org/10.4135/9781446279946

Muaris, H. (2009). Yummy \& Healthy Low Sugar Food Takjil Sehat Rendah Gula.

Munfarida, E. (1970). Peran Keluarga Di Era Budaya Konsumen. KOMUNIKA: Jurnal Dakwah Dan Komunikasi, 6(1). https://doi.org/10.24090/komunika.v6i1.333

Pattana Kitiarsa. (2007). Religious Commodifications in Asia: Marketing Gods.

Riana, G. V. (2014). Komodifikasi Nilai Agama Dalam Iklan Televisi (Studi Analisis Semiotik Komodifikasi Nilai Agama Terhadap Iklan Larutan Cap Kaki Tiga). Journal of Chemical Information and Modeling, 53(9), 1689-1699.

Sinha, V. (2011). Religion and commodification 'Merchandizing' diasporic Hinduism. In Religion and Commodification "Merchandizing" Diasporic Hinduism. https://doi.org/10.4324/9780203842799

Williams, K. (2003). Understanding Media Theory. 266.

Zulfikar, E. (2018). Tradisi Halal Bihalal dalam Perspektif Al-Qurâ€ $€^{\mathrm{TM}}$ an dan Hadis. Jurnal Online Studi Al-Qur'an, 14(2), 127-150. https://doi.org/10.21009/jsq.014.2.03 